\title{
HUBUNGAN PENGETAHUAN DAN SIKAP IBU NIFAS DENGAN PERAWATAN LUKA PERINEUM DI RUMAH SAKIT MUHAMMADIYAH PALEMBANG TAHUN 2018
}

\section{Tirta Anggraini}

Akademi Kebidanan Budi Mulia Palembang

\author{
Informasi Artikel : \\ Diterima : $\quad$ Februari 2019 \\ Disetujui : $\quad$ Mei 2019
}

"Korespondensi Penulis : tirtaanggraini1705@gmail.com

\section{A B S T R A K}

Menurut data World Health Organization (WHO) tahun 2012 sebanyak $99 \%$ kematian ibu akibat masalah persalinan atau kelahiran terjadi di negara-negara berkembang. Penyebab langsung kematian di Indonesia dan negara lainnya hampir sama yaitu akibat perdarahan (28\%), eklamsia (24\%) dan infeksi (11\%). Kasus infeksi ini $(25-55 \%)$ di sebabkan karena infeksi jalan lahir atau episiotomi. Tujuan penelitian untuk mengetahui hubungan pengetahuan sikap ibu nifas tentang perawatan luka perineum di Rumah Sakit Muhammadiyah Palembang tahun 2018. Jenis Penelitian ini berbentuk survey analitik dengan cross sectional, pengambilan sample menggunakan metode accidental sampling yaitu sebanyak 30 responden. Variabel yang dikaji dalam penelitian ini adalah pengetahuan dan sikap ibu nifas dengan perawatan luka perineum. Analisa yang digunakan adalah uji Chi-Square. Berdasarkan hasil penelitian, didapatkan responden yang melakukan perawatan luka perineum sebanyak 22 responden $(73,3 \%)$ dan yang tidak melakukan perawatan luka perineum sebanyak 8 responden $(26,7 \%)$. Responden yang berpengetahuan cukup sebanyak 13 responden $(43,3 \%)$ lebih banyak dibandingkan dengan responden yang memiliki pengetahuan kurang sebanyak 11 responden $(36,7 \%)$ dan responden yang berpengetahuan baik sebanyak 6 responden $(20,0 \%)$. Responden yang memiliki sikap positif sebanyak 23 responden $(76,7 \%)$ lebih besar dibandingkan dengan responden yang memiliki sikap negatif sebanyak 7 orang $(23,3 \%)$. Dari hasil uji Chi-Square hubungan pengetahuan dengan perawatan luka perineum didapatkan hasil $p$ value 0,001 dan hubungan sikap dengan perawatan luka perineum didapatkan hasil $p$ value 0,002 . Hasil dari penelitian ini ada hubungan bermakna antara pengetahuan dan sikap ibu nifas dengan perawatan luka perineum di Rumah Sakit Muhammadiyah Palembang tahun 2018.

Kata kunci : Pengetahuan, Sikap, dan Perawatan Luka Perineum

\section{ABSTRACT}

Data from the World Health Organization (WHO) in 2012 as many as $99 \%$ of maternal deaths due to labor or birth problems occur in developing countries. The immediate causes of death in Indonesia and other countries are almost the same, bleeding (28\%), eklampsia (24\%) and infection (11\%). Cases infection (25-55\%) are caused due to birth canal infections or episiotomi. The study was to determine the relationship between knowledge of postpartum attitudes about perineum wound care at the Muhammadiyah Hospital in Palembang in 2018. The type of this study was an analytical survey with cross sectional,sample using accidental sampling method which was 30 respondents. The variables studied in this study were the knowledge and attitudes of postpartum mothers with perineum wound care. The analysis used is the Chi-Square test. Based on the results of the study, there were 
22 respondents $(73.3 \%)$ and those who did not perform perineum wound care as many as 8 respondents (26.7\%). Respondents who were sufficiently knowledgeable were 13 respondents (43.3\%) more than respondents who had less knowledge as many as 11 respondents (36.7\%) and respondents who were well-informed as many as 6 respondents (20.0\%). Respondents who had a positive attitude were 23 respondents (76.7\%) greater than respondents who had a negative attitude as many as 7 people (23.3\%). From the results of the Chi-Square test, the relationship between knowledge with perineal wound care showed $p$ value 0.001 and the relationship between attitudes and perineal wound care showed $p$ value 0.002. The results of this study have a significant relationship between knowledge and attitude of postpartum mothers with perineum wound care at the Muhammadiyah Hospital Palembang in 2018.

Keywords: Knowledge, Attitudes, and Care of Perineum Wounds.

\section{PENDAHULUAN}

Menurut Data World Health Organization (WHO) tahun 2012 sebanyak $99 \%$ kematian ibu akibat masalah persalinan atau kelahiran terjadi di negara-negara berkembang. Penyebab langsung kematian di Indonesia dan negara lainnya hampir sama yaitu akibat perdarahan (28\%), eklamsia (24\%) dan infeksi (11\%). Kasus infeksi ini (25-55\%) di sebabkan karena infeksi jalan lahir atau episiotomi. Infeksi masa nifas masih merupakan penyabab tertinggi Angka Kematian Ibu (AKI), infeksi ini tidak bisa di biarkan karena menyebabkan kematian pada ibu nifas sebanyak 50\% (Depkes RI, 2012:54).

Salah satu infeksi pada ibu nifas yaitu infeksi pada luka perineum, oleh karena itu perawatan luka perineum penting di lakukan jika tidak dirawat dapat merupakan media yang baik untuk berkembangnya kuman dan menimbulkan infeksi, ibu menjadi panas, luka menjadi basah dan jahitan terbuka, bahkan ada yang mengeluarkan bau busuk dari jalan lahir (vagina), karena itu penting melakukan perawatan luka perineum agar tidak terjadi infeksi, komplikasi, bahkan kematian ibu post partum (Elisabeth Siwi Walyani, 2009;2).

Asuhan selama periode masa nifas perlu mendapat perhatian karena sekitar 60\% angka kematian ibu terjadi pada periode ini, oleh karena itu pengetahuan dan sikap ibu sangat berpengaruh dalam penyembuhan luka perineum karena jika pengetahuan dan sikap ibu baik maka kecil kemungkinan terjadinya infeksi pada masa nifas (Dewi, 2012;1).

Berdasarkan data yang di dapat penulis di Rumah Sakit Muhammadiyah Palembang pada tahun 2016 jumlah ibu yang sedang dalam masa nifas sebanyak 523 orang, pada tahun 2017 sebanyak 660 orang, sedangkan pada tahun 2018 dari bulan januari sampai september jumlah ibu yang sedang dalam masa nifas sebanyak 459 orang.

Berdasarkan latar belakang di atas maka peneliti tertarik untuk melakukan penelitian dengan judul "Hubungan Pengetahuan dan Sikap Ibu Nifas tentang Perawatan Luka Perineum di Rumah Sakit Muhammadiyah Palembang Tahun 2018”.

\section{METODE PENELITIAN}

Desain penelitian yang digunakan dalam penelitian ini adalah survey analitik dengan cross sectional di mana variabel independennya (pengetahuan dan sikap) dan variabel dependen (perawatan luka perineum) di ambil dalam waktu bersamaan (Notoatmodjo, 2010, 34).

Populasi dalam penelitian ini adalah seluruh ibu nifas yang datang berkunjung di Rumah Sakit Muhammadiyah Palembang tahun 2018. sebanyak 65 orang

Sampel pada penelitian ini yaitu sebagian ibu nifas yang datang berkunjung di Rumah Sakit Muhammadiyah Palembang 2018. Adapun teknik pengambilan sampel pada penelitian ini dilakukan dengan teknik accidental sampling, yaitu dilakukan dengan cara mengambil kasus atau responden yang kebetulan ada atau tersedia pada waktu penelitian. Pada saat penelitian berlangsung, peneliti benjumpa responden sebanyak 30 orang.

Analisa univarat bertujuan untuk menggambarkan secara sistematis fakta atau karakteristik populasi tertentu atau bidang tertentu secara aktual dan cermat. Analisa yang dimaksud untuk mendeskripsikan masing-masing 
variabel independen yaitu pengetahuan dan sikap pada ibu nifas variabel dependen perawatan luka perineum

Analisa bivarat dilakukan berdasarkan uji chi-square untuk menemukan bentuk hubungan statistik antara variabel independen (pengetahuan dan sikap) dan variabel dependen (perawatan luka perineum ). Hasil analisis bivarat merupakan hubungan antara masing-masing variabel dependen dan independen

.Analisa bivariat dilakukan terhadap dua variabel yang diduga berhubungan. Untuk membuktikan apakah hipotesa diterima / ditolak, dengan menggunakan $\mathrm{x}^{2}$ (chi square) .

\section{HASIL PENELITIAN}

\section{Analisis Univariat}

Analisis univariat yaitu analisis yang dilakukan terhadap satu variabel. Analisis ini dilakukan pada setiap variabel yang diteliti.

Tabel 1 Distribusi Frekuensi perawatan luka perineum Pada Ibu Nifas di Rumah Sakit Muhammadiya Palembang 2018.

No Perawatan Frekuensi Persentase luka perineum

\begin{tabular}{|c|c|c|c|}
\hline 1 & ya & 22 & 73,3 \\
\hline 2 & Tidak & 8 & 26,7 \\
\hline & Total & 30 & 100 \\
\hline
\end{tabular}
menunjukkan bahwa dari 30 responden, didapatkan responden yang melakukan perawatan luka perineum sebanyak 22 responden $(73,3 \%)$ dan yang tidak melakukan perawatan luka perineum sebanyak 8 responden $(26,7 \%)$.

Tabel 2 Distribusi Frekuensi Pengetahuan pada Ibu Nifas di Rumah Sakit Muhammadiyah Palembang 2018 N Pengetahuan Frekuensi Persentase

\begin{tabular}{cccc} 
o & & & \\
\hline 1 & Baik & 6 & 20,0 \\
\hline 2 & Cukup & 13 & 43,3 \\
\hline 3 & Kurang & 11 & 36,7 \\
\hline & Total & $\mathbf{3 0}$ & $\mathbf{1 0 0}$ \\
\hline
\end{tabular}

Berdasarkan tabel 2 menunjukkan bahwa dari 30 responden, didapatkan responden yang berpengetahuan cukup sebanyak 13 responden $(43,3 \%)$ lebih banyak dibandingkan dengan responden yang memiliki pengetahuan kurang sebanyak 11 responden $(36,7 \%)$ dan responden yang berpengetahuan baik sebanyak 6 responden $(20,0 \%)$.

Tabel 3 Distribusi Frekuensi sikap pada Ibu Nifas di Rumah Sakit Muhammadiyah Palembang 2018

\begin{tabular}{|c|c|c|c|}
\hline $\begin{array}{l}\mathbf{N} \\
\mathbf{0}\end{array}$ & $\begin{array}{c}\text { Jenis } \\
\text { persalinan }\end{array}$ & Frekuensi & Persentase \\
\hline 1 & Positif & 23 & 76,7 \\
\hline 2 & Negative & 7 & 23,3 \\
\hline & Total & 30 & 100 \\
\hline
\end{tabular}
menunjukkan bahwa dari 30 responden, didapatkan responden yang memiliki sikap positif sebanyak 23 responden $(76,7 \%)$ lebih besar dibandingkan dengan responden yang memiliki sikap negatif sebanyak 7 orang $(23,3 \%)$.

\section{Analisis Bivariat}

Analisa ini dilakukan untuk mengetahui hubungan antara variabel dependen (perawatan luka perineum) dengan variabel independen (pengetahuan dan sikap), dalam penelitian ini menggunakan uji chi-square dengan derajat kepercayaan $95 \%$, jika $p$ value $\leq \alpha(0,05 \%)$ maka ada hubungan yang bermakna antara variabel dependen dan independen

Tabel 4 Hubungan Pengetahuan dengan Perawatan Luka Perineum di Rumah Sakit Muhammadiyah Palembang Tahun 2018

\begin{tabular}{lccc}
\hline N Pengetahuan & $\begin{array}{c}\text { Perawatan luka } \\
\text { perineum }\end{array}$ & Jumlah & $\begin{array}{c}P \\
\text { value }\end{array}$
\end{tabular}

\begin{tabular}{llllllll}
\cline { 3 - 7 } & & \multicolumn{9}{c}{ Ya } & \multicolumn{3}{c}{ Tidak } & \multicolumn{1}{c}{} \\
\cline { 2 - 7 } & & $\mathbf{n}$ & $\mathbf{\%}$ & $\mathbf{n}$ & $\mathbf{\%}$ & $\mathbf{N}$ & $\mathbf{\%}$ \\
\hline 1 & Baik & 6 & 10,0 & 0 & 0 & 6 & 100 \\
\hline 2 & Cukup & 12 & 92,3 & 1 & 7,7 & 13 & 100 \\
\hline 2 & Kurang & 4 & 36,4 & 7 & 63,6 & 11 & 100 \\
\hline Jumlah & $\mathbf{2 2}$ & & $\mathbf{8}$ & & $\mathbf{3 0}$ & \\
\hline
\end{tabular}

Berdasarkan tabel 4 diatas, didapatkan bahwa dari 13 responden yang memiliki pengetahuan cukup sebanyak 12 responden $(92,3 \%)$ yang melakukan perawatan luka perineum lebih banyak dibandingkan dengan responden yang tidak melakukan perawatan luka perineum sebanyak 1 responden $(7,7 \%)$. Responden yang memiliki pengetahuan kurang sebanyak 11 responden, dimana sebanyak 7 responden $(63,6 \%)$ yang tidak melakukan perawatan luka perineum lebih banyak dibandingkan dengan responden yang melakukan 
perawatan luka perineum sebanyak 4 responden $(36,4 \%)$. Sedangkan dari 6 responden yang berpengetahuan baik semuanya melakukan perawatan luka perineum.

Berdasarkan hasil uji chi-square didapatkan nilai $p$ value $=0,001$ lebih kecil dari $\alpha$ $(0,05)$, artinya ada hubungan yang bermakna antara pengetahuan dengan perawatan luka perineum di Rumah Sakit Muhammadiyah Palembang tahun 2018 yang telah teruji secara statistik.

\section{Tabel 5 Hubungan Sikap dengan Perawatan Luka Perineum di Rumah Sakit Muhammadiyah Palembang Tahun 2018}

\begin{tabular}{|c|c|c|c|c|c|c|}
\hline \multirow[t]{3}{*}{ Sikap } & \multicolumn{3}{|c|}{$\begin{array}{c}\text { Perawatan luka } \\
\text { perineum }\end{array}$} & \multirow{2}{*}{\multicolumn{2}{|c|}{ Jumlah }} & \multirow[t]{3}{*}{$\begin{array}{c}\mathbf{P} \\
\text { value }\end{array}$} \\
\hline & \multicolumn{2}{|c|}{ Ya } & Tidak & & & \\
\hline & $\mathbf{n}$ & $\%$ & N \% & $\mathbf{N}$ & $\%$ & \\
\hline 1 Positif & 20 & 87,2 & 313,8 & 23 & 100 & \\
\hline 2 Negative & 2 & 28,6 & $5 \quad 71,4$ & 7 & 100 & $\mathbf{0 , 0 0 2}$ \\
\hline Jumlah & 22 & & 8 & 30 & & \\
\hline
\end{tabular}

Berdasarkan tabel 5 diatas, bahwa dari 23 responden, didapatkan responden yang memiliki sikap positif sebanyak 20 responden $(87,0 \%)$ yang melakukan perawatan luka perineum lebih banyak dibandingkan dengan responden yang tidak melakukan perawatan luka perineum sebanyak 3 responden $(13,0 \%)$. Sedangkan dari 7 responden yang bersikap negatif sebanyak 5 responden $(71,4 \%)$ yang tidak melakukan perawatan luka perineum lebih banyak dibandingkan dengan responden yang melakukan perawatan luka perineum sebanyak 2 responden $(28,6 \%)$.

Berdasarkan hasil uji chi-square nilai $p$ value $=0,002$ lebih kecil dari $\alpha(0,05)$, artinya ada hubungan yang bermakna antara sikap dengan perawatan luka perineum di Rumah Sakit Muhammadiyah Palembang tahun 2018 yang telah teruji secara statistik.

\section{PEMBAHASAN}

\section{Perawatan Luka Perineum}

Hasil analisis univariat menunjukkan bahwa dari 30 responden, didapatkan responden yang melakukan perawatan luka perineum sebanyak 22 responden $(73,3 \%)$ dan yang tidak melakukan perawatan luka perineum sebanyak 8 responden $(26,7 \%)$.
Perawatan perineum adalah pemenuhan kebutuhan untuk menyehatkan daerah antara paha yang dibatasi oleh vulva dan anus pada ibu yang dalam masa antara kelahiran plasenta sampai dengan kembalinya organ genetik seperti pada waktu sebelum hamil (Rukiyah, 2010;361).

Hasil penelitian ini sesuai dengan penelitian yang dilakukan Puspitarani (2010) dengan judul hubungan perawatan perineum dengan kesembuhan luka perineum pada ibu nifas hari ke enam, dari 24 orang terdapat kesembuhan lukanya tidak abik 3 orang $(42,3 \%)$ dan kesembuhan luka baik ada 4 orang $(57,1 \%)$. Sedangkan perawatan lukanya baik seluruh kesembuhan lukanya yaitu 17 orang $(100 \%)$.

\section{Pengetahuan}

Hasil analisis univariat menunjukkan bahwa dari 30 responden, didapatkan responden yang berpengetahuan cukup sebanyak 13 responden (43,3\%) lebih banyak dibandingkan dengan responden yang memiliki pengetahuan kurang sebanyak 11 responden $(36,7 \%)$ dan responden yang berpengetahuan baik sebanyak 6 responden $(20,0 \%)$.

Hasil analisis bivariat menunjukan bahwa dari 13 responden yang memiliki pengetahuan cukup sebanyak 12 responden $(92,3 \%)$ yang melakukan perawatan luka perineum lebih banyak dibandingkan dengan responden yang berpengetahuan cukup sebanyak 1 responden $(7,7 \%)$ yang tidak melakukan perawatan luka perineum. Responden yang memiliki pengetahuan kurang sebanyak 11 responden, dari 11 responden yang memiliki pengetahuan kurang sebanyak 7 responden $(63,6 \%)$ yang tidak melakukan perawatan luka perineum lebih banyak dibandingkan dengan responden yang memiliki pengetahuan kurang sebanyak 4 responden $(36,4 \%)$ yang melakukan perawatan luka perineum. Sedangkan dari 6 responden yang berpengetahuan baik sebanyak 6 responden $(100 \%)$ yang melakukan perawatan luka perineum dan tidak ada responden yang berpengetahuan baik yang tidak melakukan perawatan luka perineum.

Berdasarkan hasil uji chi-square didapatkan nilai $p$ value $=0,001$ lebih kecil dari $\alpha(0,05)$, artinya ada hubungan yang bermakna antara pengetahuan dengan perawatan luka perineum di Rumah Sakit 
Muhammadiyah Palembang tahun 2018 yang telah teruji secara statistik.

Hasil penelitian ini sesuai dengan penelitian Nurul Fajria (2012) tentang hubungan tingkat pengetahuan dan sikap ibu dengan praktik perawatan luka episiotomi postpartum di Rumah Sakit Ibu dan Anak Banda Aceh tahun 2012. Dari penelitian tersebut didapatkan hasil bahwa dari 22 responden yang memiliki pengetahuan yang tinggi diketahui 15 orang responden terdapat 7 orang responden yang melakukan perawatan luka episiotomi yang salah namun sebagian responden dengan jumlah 29 orang responden terdapat 21 orang yang melakukan perawatan luka episiotomi. Setelah dilakukan uji statistik dengan menggunakan formula chi-square didapatkan nilai $\mathrm{p}$ value $0,009<$ nilai $\alpha 0,05$ sehingga dapat diketahui bahwa hipotesa Ho ditolak yang berati terdapat hubungan tingkat pengetahuan dengan perawatan luka episiotomi post partum di Rumah Sakit Ibu dan anak Banda Aceh 2012.

Pengetahuan merupakan hasil "Tahu" dan ini terjadi setelah orang mengadakan pengindraan terhadap suatu objek tertentu. Pengindraan terhadap obyek terjadi melalui panca indra manusia yakni penglihatan, pendengaran, penciuman, rasa dan raba dengan tersendiri. Pada waktu pengindraan sampai menghasilkan pengetahuan tersebut sangat dipengaruhi oleh intensitas perhatian presepsi terhadap obyek. Sebagian besar pengetahuan manusia diperoleh melalui mata dan telinga (Notoatmodjo, 2012;138).

Berdasarkan hasil penelitian ini, peneliti berasumsi bahwa perawatan luka perineum di Rumah Sakit Muhammadiyah Palembang lebih banyak melakukan perawatan luka perineum, dibandingkan yang tidak melakukan perawatan luka perineum, karena pengetahuan sangat mempengaruhi pada kesembuhan luka perineum. Hal ini sesuai dengan teori Darmawati yaitu pengetahuan merupakan hal yang penting, pengetahuan bisa didapatkan karena pengalaman terdahulu atau informasi yang didapatkan dari orang lain. Jika pengetahuan yang dimiliki tidak mencukupi maka akan berakibat tidak baik untuk kesehatan. Perawatan luka perineum memerlukan pengetahuan yang cukup tentang perawatan luka perineum untuk mencapai kesembuhan yang baik serta terhindar dari infeksi yang menyebabkan kematian.

\section{Sikap}

Hasil analisis univariat menunjukkan bahwa dari 30 responden, didapatkan responden yang memiliki sikap positif sebanyak 23 responden $(76,7 \%)$ lebih besar dibandingkan dengan responden yang memiliki sikap negatif sebanyak 7 orang $(23,3 \%)$.

Hasil analisis bivariat menunjukan bahwa dari 23 responden didapatkan, responden yang memiliki sikap positif sebanyak 20 responden $(87,0 \%)$ yang melakukan perawatan luka perineum lebih banyak dibandingkan dengan responden yang bersikap positif sebanyak 3 responden $(13,0 \%)$ yang tidak melakukan perawatan luka perineum. Sedangkan dari 7 responden yang bersikap negatif sebanyak 5 responden $(71,4 \%)$ yang tidak melakukan perawatan luka perineum lebih banyak dibandingkan dengan responden yang bersikap negatif sebanyak 2 responden $(28,6 \%)$ yang tidak melakukan perawatan luka perineum.

Berdasarkan hasil uji chi-square nilai $p$ value $=0,002$ lebih kecil dari $\alpha(0,05)$, artinya ada hubungan yang bermakna antara sikap dengan perawatan luka perineum di Rumah Sakit Muhammadiyah Palembang tahun 2018 yang telah teruji secara statistik.

Hasil penelitian ini sesuai dengan penelitian Nurul Fajria (2012), tentang hubungan tingkat pengetahuan dan sikap ibu dengan praktik perawatan luka episiotomi postpartum di Rumah Sakit Ibu dan Anak Banda Aceh tahun 2012. Dari penelitian tersebut didapatkan hasil bahwa dari 27 responden yang memiliki sikap positif $(33,3 \%)$ terdapat 9 orang responden yang melakukan perawatan luka episiotomi yang salah, namun dari 24 orang responden dengan sikap kurang baik terdapat 19 orang $(79,2 \%)$ responden yang melakukan perawatan luka episiotomi yang salah. Setelah dilakukan uji statistik dengan menggunakan formula chisquare didapatkan nilai $\mathrm{p}$ value $0,003<$ nilai $\alpha$ 0,05 sehingga dapat diketahui bahwa hipotesa Ho ditolak yang berati ada hubungan pengetahuan dengan perawatan luka episiotomi post partum di Rumah Sakit Ibu dan anak Banda Aceh 2012.

Sikap pada umumnya sering diartikan sebagai suatu tindakan yang dilakukan individu untuk memberikan tanggapan pada suatu hal atau suatu reaksi yang mucul dari seorang individu terhadap obyek yang 
kemudian memunculkan perilaku individu terhadap obyek tersebut dengan cara-cara tertentu (Saifudi Azwar, 2010;3).

Berdasarkan hasil penelitian ini, peneliti berasumsi bahwa ibu nifas yang menjadi responden di Rumah Sakit Muhammadiyah Palembang berfikir lebih positif. Ini ditunjukkan dengan ibu nifas yang bersikap positif lebih banyak dibandingkan dengan ibu yang bersikap negatif hal ini sesuai dengan teori menurut Darmawati, yang menyebutkan bahwa sikap ibu terhadap perawatan luka perineum juga merupakan hal yang sangat penting diperhatikan oleh ibu yang mengalami episiotomi karena setiap respon yang diberikan untuk merawat luka perineum akan menentukan cepat atau lambat kesembuhan luka tersebut..

\section{KESIMPULAN}

Dari hasil penelitian di Rumah Sakit Muhammadiyah Palembang dengan judul hubungan pengetahuan dan sikap ibu nifas dengan perawatan luka perineum dapat disimpulkan sebagai berikut ada hubungan pengetahuan ibu di Rumah Sakit Muhammadiyah Palembang tahun 2018 didapatkan nilai $p$ value $=$ 0,001. Ada hubungan sikap ibu di Rumah Sakit Muhammadiyah Palembang tahun 2018 didapatkan nilai $p$ value $=0,002$.

\section{DAFTAR PUSTAKA}

A. Wawan, 2010: 20.Metode Penelitian Kebidanan dan teknik analisis data. Jakarta: Salemba Medika

Anik Maryuyani, 2014: 15. Asuhan Pada Ibu Dalam Masa Nifas. Jakarta: Trans Info Media

Azwar, Saifudin, 2012: 33. Metode Penelitian Kebidanan dan teknik analisis Data. Jakarta: Salemba Medika

Budiman, 2013: 20.Metode Penelitian Kebidanan dan teknik analisis Data. Jakarta: Salemba Medika

Darmawanti, 2012: 4.Pengetahuan dan Sikap Dalam Penelitian Kesehatan. Jakarta Selatan: Salemba Medika

Dewi, 2012: 8. Buku Ajar Asuhan Kebidanan Normal. Jakarta: EGC
Dinkes Palembang, 2013: 36. Profil Kesehatan Kota Palembang. Palembang. Dinkes Kota Palembang

Dinkes RI, 2012: 54.Profil Kesehatan Indonesia. Jakarta: KEMENKES RI

Dinkes Sumsel, 2010: 35. Profil Kesehatan. Palembang. Dinkes Provinsi Sumatera Selatan.

Elisabeth Siwi,2009 : 2.Buku Ajar Asuhan Kebidanan Nifas (Askeb III).Yogyakarta: Nuha Medika

Hidayat, Aziz Alimut, 2014: 62.Metode Penelitian Kebidanan dan teknik analisis Data. Jakarta: Salemba Medika

Kismoyo, 2011: 68.Pengetahuan dan Sikap Dalam Penelitian Kesehatan. Jakarta Selatan: Salemba Medika

Lia Yulianti, 2017: 2. Asuhan Kebidanan III (Nifas). Jakarta: Trans Info Media

Meida Lina, 2017: 5. Asuhan Kebidanan III (Nifas). Jakarta: Trans Info Media

Notoatmodjo, 2012:138. Metode Penelitian Kesehatan. Jakarta: Reniaka Cipta

Nugroho, 2014: 13.Buku Ajar Asuhan Kebidanan Nifas (Askeb III).Yogyakarta: Nuha Medika

Purwanto, 2011: 39.Pengetahuan dan Sikap Dalam Penelitian Kesehatan. Jakarta Selatan: Salemba Medika

Reber, 2010: 90.Pengetahuan dan Sikap Dalam Penelitian Kesehatan. Jakarta Selatan: Salemba Medika

Risa pitriani, 2015: 7.Asuhan Kebidanan Pada Ibu Nifas. Jakarta: Salemba Medika

RPJMN, 2014. Profil Kesehatan. Jakarta. Kemenkes RI

Rukiyah, Ai Yeyeh, 2010: 361. Asuhan Kebidanan III (Nifas). Jakarta: Trans Info Media

Saleha, 2015:4.Asuhan Kebidanan Pada Ibu Nifas. Jakarta: Salemba Medika 
Sarlito \& Eko, 2009:151.Pengetahuan dan Sikap Dalam Penelitian Kesehatan. Jakarta Selatan: Salemba Medika

Sartika, 2014:57. Metode Penelitian Kebidanan dan Teknik Analisis Data. Jakarta: Salemba Medika

SDKI, 2012: 4. Profil Kesehatan Indonesia. Jakarta. Kemenkes RI

Sulistyawati, 2015: 77.Buku Ajar Asuhan Kebidanan Pada Ibu Nifas. Yogyakarta: C. V Andi Offset

Tamburaka, Apriadi, 2012: 13.Pengetahuan dan Sikap Dalam Penelitian Kesehatan. Jakarta Selatan: Salemba Medika

Tri Sunarsih, 2014:2. Asuhan Kebidanan Pada Ibu Nifas. Jakarta: Salemba Medika

Vivian Vanny, 2014: 1.Asuhan Kebidanan Pada Ibu Nifas. Jakarta: Salemba Medika

Wawan \& Dewi, 2010: 114. Metode Penelitian Kebidanan dan Teknik Analisis Data. Jakarta: Salemba Medika

WHO, 2012. Profil Kesehatan. Jakarta. Kemenkes RI

Yanti, 2011: 85.Asuhan Kebidanan Nifas. Bandung: Aditama

Yeti Anggraini, 2010: 1. Asuhan Kebidanan Pada Ibu Nifas. Jakarta: Salemba Medika 
